\title{
Strategic Evolution of Chilean Wine Firms: Vertical Integration and Upgrading in Chile's Colchagua Valley
}

\author{
Robert N. Gwynne \\ Robert N. Gwynne, School of Geography, Earth and Environmental Sciences, University of Birmingham, \\ Birmingham,UK (r.n.gwynne@bham.ac.uk)
}

\begin{abstract}
This paper argues that the favourable export trajectories for Chilean wine to global markets in general and the UK market in particular are partly due to the nature of the insertion of wine producing firms into global value chains. Much of the data in this paper comes from a two-year British Academy research project (2005-07) which examined the impacts of globalization on export-oriented wine firms in Chile's Colchagua Valley and the record of collaboration between these firms and key purchasing companies within the UK market. The paper examines the political economy of value chains in agro-industry, retail concentration in core economy markets and the relevance of convention theory to value chains in the wine sector. The paper then analyses how value chains give context to the nature of upgrading within the Chilean wine sector by focusing on: the strategic example of the lead firm; firm upgrading as a response to the demands of and knowledge flows from retailers; and firm upgrading through the flying winemaker model. The paper will conclude by assessing the relevance of the Chilean experience for other countries wishing to rapidly expand their wine exports, such as those in S. E. Europe.
\end{abstract}

Keywords: Chile, wine production, UK, political economy, value chain

\section{Introduction}

This article examines how vertical integration and upgrading impinge upon firms within an agro-industrial sector of one Latin American country, namely Chile. The sector chosen for analysis in this paper is that of wine in Chile, notable for considerable export growth over the past two decades (Gwynne, 2006b; Gwynne 2008a). As Sturgeon (2001: 9) argued studies of industry value chains reveal the concrete actors at the global scale as well as the linkages that bind them into producing regions (Hayward and Lewis, 2008). The Chilean wine sector has developed an impressive export record over recent years. In the penultimate year of the Pinochet dictatorship, 1988, Chilean quality wine exports, with a wine geographical denomination, were a meagre US\$17.9 million (Banco Central, 1990); by 2007 they had reached US\$1,012 million (Banco Central, 2008) - a growth of 56 times in only 19 years.

The Chilean wine sector has become completely restructured. In 1988, Chile was producing around 300 million litres of wine annually, of which only 7 per cent was exported; by 2007 around 800 million litres were being produced with 70 per cent for export; by 2014 the Chilean Ministry of Agriculture forecasts production of 1.2 billion litres with 85 per cent destined for export (Richards, 2006).

One key research issue that value chain methodologies facilitate is the process of technological upgrading, both in terms of product and process (Humphrey, 2005; Humphrey and Schmitz, 2002). Agro-industrial policy themes have a number of firms 
in countries of the semi-periphery (Humphrey, 2006). Firms need to respond to information flows going through the value chain and the requirements of supermarket and other retail buyers in core economy markets (Humphrey and Schmitz, 2001). Within the wine sector, upgrading can occur through improved raw material supply (the quality of wine grapes), investment in process technology (stainless steel fermentation tanks and oak barrels for example), the increasing utilization of flying winemakers (Lagendijk, 2004) and the more studied formulation of the final product in terms of targeted markets (Guthey, 2008).

Vertical integration in Chilean wine firms have developed a different strategy to such firms in South Africa (Gibbon and Ponte, 2005; McEwan and Bek, 2006). In South Africa, wineries and vineyard owners are seeking to promote vertical disintegration which allows wineries to adopt a policy of upgrading and to trade down through the large number of vineyard owners in the countryside. Wineries are essentially selling off their land to grape growers and then buying in the grapes. There is a vertical disintegration of production - they are attached with a lack of control of quality for their better wines but in terms of the larger wineries they can achieve greater benefits of large economies of scale. In terms of functional upgrading, two parallel processes are taking place in the value chain for South African wine. It is a classic vertical disintegration process, where cellars and producer-wholesalers are moving away from (or reducing their engagement in) grape-growing. In contrast, in Chile, the emphasis for wineries has been to upgrade their own vineyards by improving technological concerns and the quality of the wine grape for international markets.

Most Chilean wine firms are still national rather than international (see Table One). Most firms seek to provide vertical integration by investing in their own purchasing and planting vineyards throughout their regions. This article examines how value chains of Chilean wine firms see three themes as innovative and transformative product, process and functional upgrading. In particular, Chilean wine firms that have become involved in vertical integration see their strategies as purchasing and planting more and more of their own vineyards in different producing regions. This has allowed Chilean wine firms to examine product upgrading and the agro-industrial theme of process upgrading. In addition how do firms continue to upgrade and innovate through the flying winemaker model? Finally it is useful for value chains to link into global marketing links.

\section{Value chains and agro-industry}

One dimension that value chain analysis examines is the governance structure - the authority and power relationships that determine how financial, material, and human resources are allocated and flow within a chain. The nature of power relations exist along a chain and the search is for how key actors within the chain generate and attempt to appropriate value. At least three stages of upgrading (Humphrey and Schmitz, 2002) can be seen as how actors in wineries and international supermarkets view the wine sector in Chile:

- Product upgrading - moving into more sophisticated products of wine and gradually improving the range of new product as against more traditional products.

- Process upgrading - achieving a more efficient transformation of inputs into outputs that improves the process of vineyards as one example.

- Functional upgrading - acquiring new functions (or abandoning old ones) that increase the skill content of activities, such as achieving either better vertical integration or reducing vertical disintegration into the system. 
The useful theme of the Chilean wine firm is that many of the larger firms have sought out their target to develop better product and process upgrading since the early 1990s (Visser and De Langen, 2006). However, since then, some of the more expensive export prices have done this in order to achieve functional upgrading - or to achieve greater vertical integration for the firm to produce more and more vineyards. Estate managers and winemakers can specialise larger plantings with lower yields in their new vineyards so that they concentrate more reduced wine grapes and improve the quality for international exports (Middleton, 2008; Richards, 2006). As a result, the wine firm actors are doing this so as to rely more on owning land from vertical integration (and their own estate managers) and to achieve less quality from external grape farmers that formerly they relied on in the 1980s and 1990s.

There are at least two issues that agro-industrial firms from countries of the semi-periphery should consider as they develop transactional relationships with powerful global buyers from the core economies. First is the issue of market access. Even when core countries dismantle trade barriers to the import of agricultural and agro-industrial goods, producers in the semi-periphery and periphery do not automatically gain market access (Humphrey and Schmitz, 2001). This is because the value chains that producers feed into are often governed by a limited number of core country buyers intent on generating value. Through a number of annual contracts, this normally signifies the core country buyers requiring products with increasing quality at lower, or at least, similar prices. Nevertheless, in order to participate in export production for the key global markets of North America and the European Union, producers need access to the lead firms and buyers of these chains (Friedland, 2005; Gereffi, 1999).

Secondly, becoming part of a value chain could offer firms a fast track to the acquisition of production capabilities. Those producers that gain access to the chains' lead firms tend to find themselves on a steep learning curve. The lead firms are very demanding with regard to reducing cost and raising quality, but they also transmit best practices and advice. Thus local producers can learn a great deal from global buyers about how to improve their production processes and attain consistent and high quality. Research into agro-industrial value chains must be informed and framed by global value chain studies both in manufacturing on the one hand and agriculture on the other.

Firm creation and firm restructuring for sales in exterior markets has been demonstrated to have occurred in the 1990s but how have these firms changed and developed from this time to the present day? How have they gained their success in the global market in which Chile has the fifth highest export value in the world (Olavarria et al, 2008)? The transition to open market economies in Chile gave these newly created, or newly exporting wine firms in Chile the chance to produce for the global market but the challenge faced by Chile's wine sector was the ability to produce a competitive product for the global market (Gwynne, 2003; Gwynne, 2006a). Humphrey (2006) says that to be competitive one needs to upgrade a product; innovate to differentiate. A differentiated product is harder to be found elsewhere so therefore it becomes more competitive in the global market. Furthermore, in the early 1990s in Chile, the tradition to democracy meant that global consumers who had previously boycotted Chilean products, due to human rights issues arising from the military regime, were willing to buy Chilean products again.

Another reason for firms to innovate and improve their product is to increase the value added on the global value chain. The global value chain is the market process that connects the spheres of production to the spheres of consumption in the core economies (Gwynne, 2009). In this chain there is an overwhelmingly disproportional amount of 
power and value added in the 'downstream' of the chain, that of the supermarkets in the core economies. As much as 79 per cent of Chilean wine in the U.K is sold in the offtrade, and of this $60 \%$ is sold via the top four supermarkets (Gwynne, 2008b). Firms need to differentiate and innovate so that they can stand out amongst the huge number of suppliers to these big chains.

As Gwynne (2008a) says firms are also required to innovate as supermarkets nowadays, instead of just reselling a product, actively seek out or demand a certain type or characteristic of a product. For a firm of the semi-periphery to survive in this competitive global market they need to respond from any diffusion of knowledge a distributor offers about consumer demands (Gwynne, 2008a). It is indisputable that innovation is important in the evolution and survival of firms, shown by the fact that 70 per cent of firms in Colchagua think innovation in both process and product is vital (Olavarria et al, 2008). Firms are focused on both improving the quality of vineyards (agriculture) and the manufacturing stage of improving the quality of wine production.

\section{Chilean wine firms and functional upgrading}

This research has examined the twenty largest wine firms in 2007 in Chile in terms of exports of bottled wine to all world markets (see Table 1). They all correspond to those exporters that had more than US\$14mn of exports to all global markets in 2007. When were these businesses created? There are twenty firms with dates. ${ }^{1}$ Virtually half of the companies come from the nineteenth century and the other half from the export boom of the late twentieth century. Most of those firms from the late twentieth century have concentrated on smaller production totals and improving the quality of wine - as through the details of price per litre (see Table 1).

Table 1: The record of bottled wine exports from Chile's main twenty wine companies, 2007

\begin{tabular}{|c|c|c|c|c|}
\hline $\begin{array}{l}\text { Wine Firm and } 2007 \\
\text { Export Rank }\end{array}$ & $\begin{array}{l}\text { Year Firm } \\
\text { Started }\end{array}$ & $\begin{array}{l}\text { Export Value \$mn } \\
2007\end{array}$ & $\begin{array}{l}\begin{array}{l}\text { Export } \\
\text { (mn litres) }\end{array} 2007 \\
\end{array}$ & $\begin{array}{lrr}\begin{array}{l}\text { Price per } \\
\text { (US\$) }\end{array} 2007 & \text { litre } \\
\end{array}$ \\
\hline 1. Concha y Toro & 1883 & 239.3 & 88.5 & 2.70 \\
\hline 2. Cono Sur & 1993 & 57.2 & 22.6 & 2.53 \\
\hline 3. San Pedro & 1865 & 56.7 & 23.1 & 2.45 \\
\hline 4. Santa Rita & 1880 & 50.2 & 11.5 & 4.36 \\
\hline 5. Montes & 1988 & 37.7 & 6.2 & 6.08 \\
\hline 6. Santa Carolina & 1875 & 29.8 & 11.1 & 2.69 \\
\hline 7. Errazuriz & 1870 & 28.6 & 4.9 & 5.84 \\
\hline 8. Tarapaca & 1874 & 24.5 & 7,5 & 3.27 \\
\hline 9. Ventisquero & 1998 & 23.7 & 7.9 & 3.00 \\
\hline 10. Undurraga & 1885 & 22.2 & 7.1 & 3.13 \\
\hline 11. Via & 1998 & 21.8 & 8.9 & 2.45 \\
\hline 12. Luis Felipe Edwards & 1976 & 21.5 & 8.5 & 2.53 \\
\hline 13. Maipo & 1948 & 20.2 & 9.4 & 2.15 \\
\hline 14. Santa Helena & 1942 & 20.1 & 8.5 & 2.36 \\
\hline 15. Carmen & 1850 & 19.3 & 4.5 & 4.29 \\
\hline 16. Emiliana & 1986 & 18.1 & 7.3 & 2.48 \\
\hline 17. Montgras & 1992 & 16.6 & 4.8 & 3.46 \\
\hline 18. Corpora & 1989 & 16.4 & 4.2 & 3,9 \\
\hline 19. Los Vascos & 1975 & 16.2 & 3.4 & 4.77 \\
\hline 20. Casa Lapostolle & 1994 & 14.9 & 1.9 & 7.84 \\
\hline
\end{tabular}

Source: Wines of Chile database and own research funding database

\footnotetext{
${ }^{1}$ A large number (8) were created in the late nineteenth century - Concha y Toro, San Pedro, Santa Rita, Santa Carolina, Errazuriz, Undurraga, Tarapaca and Carmen. And then another 10 were created between 1976 and 1998 Cono Sur, Montes, Via, Ventisquero, Los Vascos, Viñedos Emiliana, Luis Felipe Edwards, Montgras, Casa Lapostolle and Corpora.
} 
Wine expansion shows that the growth in exports sales has risen from $\$ 20$ million in quality bottle sales in 1990 to quality exports of over $\$ 1000$ million in 2007. Additionally, it was only from the 1990s that foreign firms started investing in Chilean wineries. This increase in foreign capital meant that there was easier access to better price ranges, better channels of distribution and new technology (Olavarria et al, 2008, Gwynne, 2008a). The technological revolution that had occurred in Australia and California (Gwynne, 2006a) influenced Chile to try to use these new techniques. This led to an examination of the different climates within Chile. This also led to the first plantings in Casablanca, where the climate was improved for white wines due to cold fogs and clouds that come in from the Pacific (Sotta, 2008) and promoted the climatic and terroir variations behind wine grape production.

How do Chile's main twenty wine firms achieve technological upgrading and vertical integration to organize their different strategies for growth? Within the twenty main firms there are those that achieve high export prices, such as Casa Lapostolle with over $\$ 7.84$ per bottle, to those much lower - discussing $\$ 2.15$ per bottle in terms of Maipo. However, there are six firms with export prices of over $\$ 4$ per quality bottle and another 14 firms operate with export prices of between $\$ 2$ and $\$ 4$ each. Firms operate with product, process and marketing upgrading in order to achieve rapid growth, such as Montes and Casa Lapostolle in particular; both of these operate as flying winemakers at the moment.

\section{Product upgrading}

The traditional style of Chilean winemaking was common as recently as the eighties. A chronic lack of investment together with an insular mentality meant that winemaking for many Chileans was a crude and haphazard business (Richards, 2006: 30). Pressing was quick and brutal, fermentations were short and hot, maceration times were kept to a minimum for fear of bacterial spoilage and filtering was conducted as early and comprehensively as possible.

Product upgrading is normally defined as moving into more sophisticated product lines, with more value-added. In the wine sector this could signify the firm starting with the production of basic wine and then gradually improving the product and moving up through the various quality categories - varietal, premium, super-premium and even ultra-premium. This would involve a slow but sustained strategy of upgrading by the wine firm. It means developing new higher-quality products in a range of new wine grapes and starting to supply international markets.

One man credited with starting innovations in Chile is the Spanish winemaker Miguel Torres, who imported modern winemaking technology such as stainless-steel tanks and pneumatic presses in the 1980s. His example of rigorous cellar hygiene, making white wines reductively, gentle pressing, and temperature-controlled fermentations proved influential (Richards, 2006: 31). These processes became widely disseminated so that the decade of the 1990s saw considerable improvement in wineries and investment in new technologies. According to Lapostol (2008), the need to delay the fermentation in order for it to be slow, especially for white wines, was one of the more important inventions, particularly for wines with aromas.

For Cox (2008) the most significant changes have been in terms of Colchagua's two new wines, Syrah and Carmenère, on its Luis Felipe Edwards estate near Nancagua (see Figure 1). Cox has planted Syrah and many other vines on a range of 800 hectares of hilly land in their property in Colchagua. Meanwhile, Carmenère, which has become the signature grape of Chile, does well on the more granitic and more fertile soils at the 
base of the hills and near to the company's cellar. Meanwhile, the traditional survivor, Cabernet Sauvignon, does well in both lower hills and plains.

Grape quality has also been improved in wineries in the Colchagua valley using a vast range of new technologies. As much as 70 per cent of money spent on innovation in Colchagua has been spent on acquiring new machinery for the vinification process (Olavarria et al, 2008). One example in Colchagua valley is the use of developing a Global Positioning System, (such as Montes and Montgras), to work out the order in which grapes in the vineyard should be harvested and how to improve the standard of each block of individual vines for each future year, as in terms of maximizing drip irrigation.

Casa Lapostolle had the highest price per litre in 2007 of the twenty largest wine firms (see Table 1). Innovations in the 'bodega' (or winery) dominated in the 1990s and since 2000 the winery has been more about planting new wine grapes in the new Apalta estate.

\section{Process upgrading}

Between 1995 and 2000 the country's vineyard underwent a massive expansion, effectively doubling in size. Chilean viticulture pushed up into the hills (away from the former plains) and towards other wine regions - in the north (Elqui), the east (Andean Foothills), the south (Bio Bio) and western Coastal Range (Casablanca, San Antonio and parts of coastal Colchcagua).

This links into the idea of process upgrading. This reorganized the production system or introduced superior technology. The introduction of stainless steel fermentation tanks with strict temperature control and an effective policy towards the supply of oak barrels are two examples. Winemakers are significant here as they introduce the knowledges of how to best organize the process in order to achieve the marketable product required. One example would be the slow and low-temperature fermentation of white grapes (such as Sauvignon Blanc) in order to maximize the fruitdriven component of the final product.

\section{FIGURE ONE: COLCHAGUA VALLEY WINERIES - 2008}

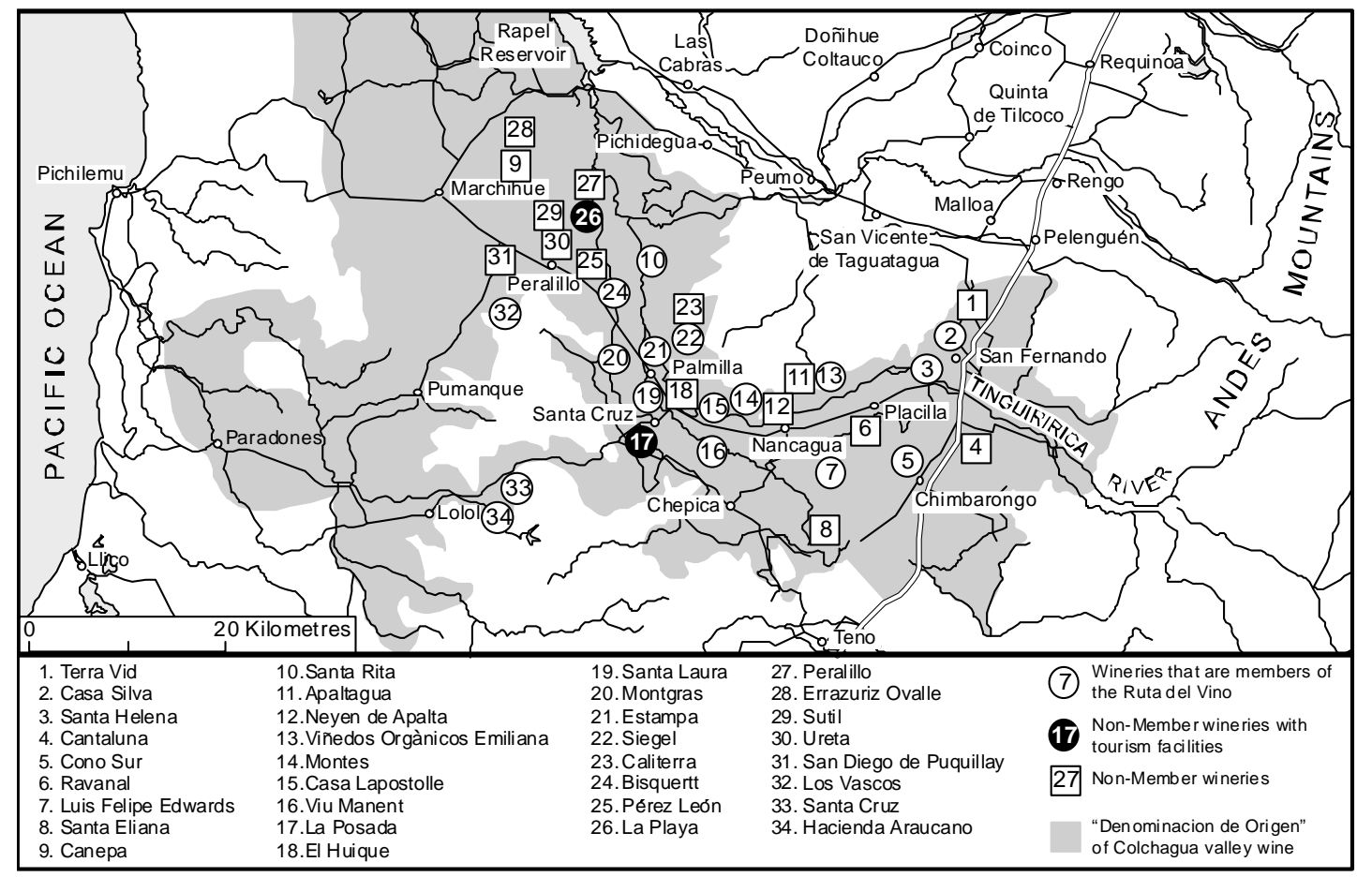


Furthermore, in agro-industry there is often the need to improve the quality of the raw material input. This has led to a distinct process of vertical integration as wine firms purchase large amounts of new land (to plant new vines) in their newly-purchased territories on hills and coastal regions in the Colchagua Valley. The wine sector contradicts the lessons of most agro-industrial firms as the wine firm has to reduce wine grape yields in the vineyard in order to maximise the subsequent quality of the wine. Water and irrigation are of increasing importance in Chilean viticulture. Irrigation is needed in most of the country's vineyards because the growing season is so dry. In 2007/08 there was no rain from the end of July to a small amount of rain in February (Lapostol, 2008). During this period, those that did not have access to water suffered considerably, and the Merlot grape in particular began to shrivel.

One form of upgrading to have taken place has been vertical integration of wine firms to increase the number of grapes coming from their own vineyards. There can be more control on production processes. At present, Colchagua valley has 7,774 hectares of land planted and 80 per cent of this land belongs to wineries, 11 per cent is rented land from farmers and 9 per cent of farmers are supervised by the wineries buying the grapes (Olavarria et al, 2008).

A case study of upstream integration is Montes winery. Serrano (2008) talks about when the winery was set up in 1988 all grapes came from farmers, and in 1991 the company bought its first property in Apalta and started producing its own grapes. Montes later increased its vertical integration even more when a new estate was bought in Marchihue, nearer to the coast in Colchagua (see Figure One). Montes has moved from 100 per cent outsourcing of farmer grapes in 1990 to only 30 per cent in 2008, when Apalta and Marchihue were the major estates. Vertical integration has been highly dynamic in an 18-year period of planting grape vines on its two estates and improving quality for export markets. It is interesting to note that Montes is not planning to integrate themselves further upstream. They will use the 30 per cent from contract farming to buy grapes from other regions, where the terroir is better suited for different wines (such as Casablanca) than those produced in Colchagua.

\section{Firms upgrading through the flying winemaker model}

We have noted that from Chile's twenty largest corporations that there are at least six firms with over US\$4 per litre in 2007, which essentially specialize in "created" winemaking and more expensive quality wine bottle for export categories. ${ }^{2}$ They did not start wine exports by supplying own-label wine for supermarkets. Flying winemakers claim that they understand the links between spaces of consumption and spaces of production so that they are better able to make better judgements than most about which type of wine each country should produce for different global markets and the type and quality of each of these wines.

Casa Lapostolle, advised by the flying winemaker, Michel Rolland, is owned by the French Marnier-Lapostolle group. Indeed their target market has been the United States (receiving around 60 per cent of firm exports) where retail concentration has allowed greater margins than those in the UK. These firms have emphasized the importance of the flying winemaker in their operations such as Michel Rolland, the Pomerol-based "star" of the film about globalization and wine, Mondovino. Lagendijk (2004: 523) sees "flying winemakers as quality and marketing symbols" themselves, able to impart success to their wine product through their name being on the label. There is, however, a further issue here - the links between flying winemakers and wine

\footnotetext{
${ }^{2}$ Of the six firms there are two linked to foreign corporations (Casa Lapostolle and Los Vascos) and four to Chilean companies (Montes, Santa Rita, Errazuriz and Carmen).
}

Urbani izziv, volume 23, supplement 2, 2012 (special issue) 
critics - a component of what Lagendijk refers to as the cultural circuit of the wine sector. In the critical US market, the most influential wine critic is Robert Parker and he has a long history of giving high evaluations to wines in which Michel Rolland has been involved. Hence there is the logic of the Casa Lapostolle creating and developing an upgrading strategy. It has relied on Michel Rolland to introduce modern technologies and Pomerol winemaking knowledges to its vineyards and winery and has then focused on selling the quality wine to the US market, where such wines as Clos Apalta have achieved iconic status.

Aurelio Montes has become the first main winemaker in Chile, with his winery and most of his vineyards in the Colchagua valley. In 2005 he was made the Salvador Izquierdo award by the Chile's Society National of Agriculture (established since the 1850s) for entrepreneurship in agriculture and was the first winemaker ever to win the prize (Ross, 2006: 16). In the vineyards, Montes acknowledges that " 80 per cent of a great wine is made in the vineyard, and 20 per cent in the winery". In 1993, Montes began his vineyard by purchasing the Apalta property in Colchagua with 120 hectares under the vines of 700 hectares of steep hills and slopes. Montes wanted to plant up on the hillsides (no greater than $45^{\circ}$ ) and onto the slopes in order to produce better quality wine for the new Syrah wine grape from the French Rhone valley. Apalta had two contrasting soil types. The flatter part is clay-like. The second part on the steep slopes is poor and well-drained, comprising a top layer of reddish clay and sand, under which lies 3 to 4 metres of granitic soil (Ross, 2006: 44). Grapes require drip irrigation to gain water supply. In addition Montes created a high density of planting to reduce plant vigour $-6,667$ vines per hectare as opposed to the Chilean norm in the mid-1990s of 3,700 per hectare. The Apalta is also like a south-west crescent, which only has sun in the morning and is less provided by the north sun. The Montes theme has been to replace the Syrah iconic wine grapes (called Montes Folly) on these high hill slopes.

\section{Upgrading in Marketing and branding}

Most producers through flying winemakers have organized developing their concept of expensive quality wine bottles for more and more varied export categories. However, one group of top-twenty Chilean wine companies has also followed the model of basing their export strategy on sustained upgrading and supplying key supermarkets in core country economies. Some firms are normally newly-established (less than 20 years old). They first inserted themselves into international markets by producing highly competitive basic and varietal wine (good quality, low prices) and have subsequently tried to steadily upgrade their quality and increase their prices.

One example of this strategy is seen in the performance of Montgras. Between 2000 and 2004 nearly 50 per cent of its production was linked to a massive export of varietal wine to Sainsburys for the latter's Christmas special offer. Whereas this gave the firm economies of scale in terms of production, per unit profit or value was very low indeed. In 2005 Montgras decided to stop this deal; export volumes understandably declined by 37.6 per cent, export values were down only 18.9 per cent as the average price per litre rose in a startling way over a one-year period - from US\$2.65 in 2004 to US\$3.46 in 2005. This shows the trade-off in terms of prioritizing the supply of UK supermarkets - high volume growth alongside supermarkets receiving the greater share of the value in the chain (Arnold et al, 2002).

Other firms that have followed this upgrading strategy include Ventisquiero and Via. In 2005, Via and Ventisquero had average export prices of only US\$1.42 and US\$1.97 per litre respectively which implies that they are at the beginning of this upgrading process; Via and Ventisquero are the major suppliers of own-label wines to 
the UK's largest supermarket, Tesco. However, between 2004 and 2005 they recorded the fastest growing exports of all top twenty Chilean wine companies. All these firms have an upgrading strategy closely linked to the product requirements of key retailers in core country markets, particularly that of the UK; Via and Ventisquero had 39 and 45 per cent of their exports respectively go to the UK market in 2005.

Table 1 shows the top 10 countries to whom Chile exported wine in 2007. One can see that the UK constitutes the main country with exports of over US\$230 million and at a median price of 2.27 dollars per litre. Germany and China generate much more imports in terms of liquid imported but their respective merits of $\$ 1.2$ for Germany and $\$ 0.57$ for China makes them the importers of very much the cheaper wine. In contrast, the US and Ireland at over $\$ 3.0$ per litre have higher quality than the average. This gives the background to the tremendous range of countries and companies that Chilean wine can export to. In the middle, as the key market, is the UK with high sales but at reduced prices for each unit exported. Higher sales growth can be achieved for those exporting to the US and Irish markets as with Casa Lapostolle and Montes. Meanwhile, for cheaper wine, the targets seem China and Germany.

Table 2: Principal export destinations for wine from Chile

\begin{tabular}{lccl}
\hline Country & Exports $(000$ liters $)$ & Exports $(000$ dollars FOB $)$ & Price per liter \\
\hline UK & 101,680 & 230,584 & 2.27 \\
USA & 61,206 & 185,743 & 3.03 \\
Germany & 59,089 & 70,895 & 1.20 \\
Canada & 29,814 & 68,361 & 2.29 \\
Denmark & 28,609 & 55,614 & 1.94 \\
Holland & 22,471 & 54,233 & 2.41 \\
Brazil & 18,896 & 50,879 & 2.69 \\
Ireland & 12,183 & 43,890 & 3.60 \\
China & 70,658 & 40,196 & 0.57 \\
Japan & 15,772 & 36,393 & 2.31 \\
Venezuela & 17,914 & 33,290 & 1.86 \\
Finland & 12,122 & 33,135 & 2.73 \\
\hline Source: Win
\end{tabular}

Source: Wines of Chile (2008)

Chile has been highly successful in the creation of export markets. They sell to eight of the ten highest importers in value terms, and of the two that are not in this category, Ireland has sales of over 100 million dollars and Brazil has sales of between \$50- \$100 million dollars (ODEPA, 2005). From interview data we can see that companies from the Colchagua Valley are also aiming at emerging markets such as China (Bisquertt, Siegel), Korea (Siegel, Bisquertt) and Russia (Luis Felipe Edwards).

Not only have Chilean firms aimed at the most emerging wine consumption markets, some Chilean firms have also been able to develop their brand successfully in certain markets, through what Gereffi et al (2005) calls 'organizational success'. In this firms start at the lower end of the market and work up to the higher end with better quality and better prices. A prime example of this from the Colchagua valley came through interviews with Luis Felipe Edwards (2008). The winery under the same name has been able to increase its sales from 70,000 cases in 2000 to one million cases in 2007 and has invested significantly in its vineyard estates.

This organizational success can be done by collaborating with supermarkets and creating a wine for their own label. This is a good way to get oneself known by the supermarkets and then by the consumers. Tesco, Sainsbury and Asda spent 20 to 40 million pounds to promote their own brand labels in 2000, and this is the kind of promotion that Chilean wineries cannot afford to spend (Chaney, 2004). 


\section{Concluding Remarks}

Chilean wine firms have managed to create not only rapid export growth but also a number of innovative and transformative themes that have impacted upon economic upgrading. Many of the twenty major firms have been distinctly dynamic although one or two of the older companies are still relatively slow compared to the new growth companies. In contrast most of the new wine companies (approximately ten of the twenty in the last two decades of the twentieth century) have embarked upon dynamic export growth and significant vertical integration as well. We focus on upgrading in an agro-industrial sector in which the quality of agriculture (vineyards) is as important as that of manufacturing (winemaking).

Meanwhile, there are a small number of distinctive quality wine firms that occur in both Colchagua and in other regions as well. The flying winemakers of Aurelio Montes of Chile and Michel Rolland from France have truly revolutionized this sector over two decades. Although Casa Lapostolle and Los Vascos do have French capital interest they are only two of the twenty main foreign firms in this sector. Most of the Chilean firms are strongly national, comparing them with large firms in both New Zealand and South African wine in which they are distinctly more global in character (Gwynne, 2006b). Chilean manufacturing and agro-industrial wine firms have managed to generate much more than one billion US dollars of quality bottle exports and with over 200 firms as well.

Some of these producers are now buying in other valleys - so that their spread of wines (particularly in white versus red) can be no longer linked to just one valley. There has been an interesting shift in vineyard location in Chile. When the Chilean wine sector was oriented towards the domestic market, vineyard locations on the flat plains of the longitudinal Central Valley and transverse valleys were favoured. This produced high yields of most grapes but reduced the quality and complexity of the final product. Since the 1990s, major Chilean wine firms have been planting vineyards in 'new' zones such as slopes and hillsides along the transverse valleys, along the Coastal Range and on the Andean piedmont. Here yields are much reduced but, if these vineyards are carefully managed in terms of access to water, they can produce the raw material for much improved wines.

In contrast, many Chilean wine firms have developed the competences to supply a range of supermarkets in an increasingly large number of countries. Rapid export growth has particularly occurred with those countries where the process of retail concentration has been significant. The Chilean wine producer has been able to establish a certain amount of bargaining power within the value chain, much more, for example, than large-scale farmers within Chile's fruit value chain (Gwynne, 2003; Murray, 1997). Value chain analysis is very much framed by the nature of the particular sector as it develops at the global scale (Friedland, 2005). Unlike global value chains in agriculture, wine provides an example of an agro-industrial value chain in which significant value-added can occur in the processing plant (winery). In contrast to such agricultural products as wheat or grapes where global exchanges tend to set prices, the wine sector has much greater flexibility in price setting and can potentially generate a huge variety of products. Prices have to be negotiated between producers and retailers rather than set in an exchange. The role of technological upgrading (through both product and process) becomes important as this can act to differentiate the final products of an exporting firm.

Technological change has not only come from the classic Old World countries such as France that have always strongly influenced the style of Chilean wine production but also from New World countries such as Australia and New Zealand 
(Richards, 2006). Thus the geographical sources of information flows for research into new process and product technologies (such as France and Australia) are different from the main geographical sources of knowledges relating to sales and marketing (such as the UK). This is an example of Lagendijk's (2004) concept of interconnected locales. Places of winemaking in one country (which are spread along a 1,200 kilometre axis in Chile) are connected to places of exchange and consumption in another. At the same time, these places are connected to knowledge centres in other countries, such as the Pomerol region in France (where flying winemakers such as Michel Rolland are based) or the Adelaide region in Australia (home to Roseworthy, one of the world's leading wine universities, and another group of flying winemakers).

The 'systemworld' of the wine value chain thus not only links producing spaces with consuming spaces but also links these with the spaces that generate technology and the applied knowledges of wine. The systemworld also involves the 'cultural circuit' of the wine sector - wine associations, trade journals, websites, wine critics and journalists, scholars and experts. Some Chilean wine firms have been able to forge export growth by harnessing the potential of the cultural circuits as well as the value chains of the global wine sector.

\section{Acknowledgements}

This data comes from a two-year British Academy research project (2005-2007) and further research which examined the impacts of globalization on export-oriented wine firms in Chile's Colchagua Valley and the record of upgrading and vertical integration between these firms. This permitted a more detailed perspective of the nature of the relationships that Chilean export-oriented wineries established with the major world markets for its wines.

In this paper I have mentioned some of the interviews as part of my research by such owners as Bisquertt, Edwards and Siegel, winemakers such as Caballero (Montes), Gatica (Santa Rita), Padilla (Cono Sur) and Phelps (Viu Manent) and estate managers such as Cox (Luis Felipe Edwards), Lapostol (Siegel) and export managers such as Eguiguren (Casa Lapostolle), Fernandez (Santa Rita), Middleton (Montgras) and Serrano (Montes).

\section{References}

Arnold, D., De Royere, A. and Stevenson, H. (2002) "Montgras: Export stratergy for a Chilean winery". Harvard Business School.

Banco Central de Chile (1990) Indicadores de Comercio Exterior, Diciembre 1989, Santiago.

Banco Central de Chile (2008) Indicadores de Comercio Exterior, Cuatro Trimestre de 2007. Santiago.

Chaney, I M (2004) Own-Label in the UK Grocery Market. International Journal of Wine Marketing, 16, 3, pp.5-9.

Friedland, W H (2005) Commodity systems: forward to comparative analysis. In Fold, $\mathrm{N}$ and Pritchard, B (eds) Cross-continental agro-food chains. Taylor and Francis, pp.25-38.

Gereffi, G. (1999), International trade and industrial upgrading in the apparel commodity chain. Journal of International Economics 48, pp. 37-70.

Gereffi, G (2005) The global economy: organization, governance and development. In Smelser, N and Swindberg, R (eds) The Handbook of Economic Sociology.. $2^{\text {nd }}$ Edition, Princeton, NJ: Princeton University Press, Chapter 8. 
Gibbon, P and Ponte, S (2005) Trading Down: Africa, Value Chains and the Global Economy. Philadelphia: Temple University Press.

Giuliani, E and Bell, M (2005) The micro-determinants of meso-level learning and innovation: evidence from a Chilean wine cluster. Research Policy, 34, 47-68.

Guthey, G T (2008) Agro-industrial conventions: some evidence from northern California's wine industry. Geographical Journal, 174, 2, 138-148.

Gwynne, R N (2003) Transnational Capitalism and Local Transformation in Chile. Tijdschrift voor Economische en Sociale Geografie, 94, 3, 310-321.

Gwynne, R. N. (2006a) "Export- orientation and Enterprise Development: A comparison of New Zealand and Chilean wine production". Tijdshrift voor economische en Social Geografie, 97, 2, pp.381-

Gwynne, R N (2006b) Governance and the wine commodity chain: upstream and downstream strategies in New Zealand and Chilean wine firms. Asia Pacific Viewpoint, 47, 3, pp.405-419.

Gwynne, R. N. (2008a) "UK retail concentration, Chilean wine producers and value chains". The Geographical Journal, 174, 2, pp.97-108.

Gwynne, R. N. (2008b) Editorial: Value chains and the geographies of wine production and consumption. The Geographical Journal, 174, 2, pp.95-96.

Gwynne, R. N. (2009) "Creating palate geographies: Chilean wine and UK consumption spaces". In Goodman, D, Goodman, M and Redclift, M (eds) Consuming Space(s) and Place(s): Placing Consumption in Perspective. Ashgate. (forthcoming)

Hayward, D and Lewis, N (2008) Regional dynamics in the globalizing wine industry: the case of Marlborough, New Zealand. Geographical Journal, 174, 2, 124-137.

Humphrey, J (2005) Shaping Value Chains for Development: Global Value Chains for Development. Report commissioned by Germany's Federal Ministry for Economic Cooperation and Development.

Humphrey, J (2006) Policy Implications of Trends in Agribusiness Value Chains. The European Journal of Development Research, 18, 4, pp.572-592.

Humphrey, J and Schmitz, H (2001) Governance in Global Value Chains. IDS Bulletin, 32, 3, pp.19-29.

Humphrey, J and Schmitz, H (2002) How does insertion in global value chains affect upgrading in industrial clusters? Regional Studies, 36, 9, pp. 1017-27.

Lagendijk, A (2004) Global 'Lifeworlds' versus local 'systemworlds': How Flying Winemakers produce Global Wines in Interconnected Locales. Tijdschrift voor Economische en Sociale Geografie, 95, 5, 511-526.

Le Heron, R (1993) Globalized Agriculture: Political Choice. Oxford: Pergamon.

Marsden, T K and Arce, A (1995) Constructing quality: emerging food networks in the rural transition. Environment and Planning A, 27, pp.1261-79.

McEwan, C and Bek, D (2006) (Re)politicizing empowerment: lessons from the South African wine industry, Geoforum, 37, 1021-1034.

Murray, W E (1997) Competitive Global Fruit Export Markets: Marketing Intermediaries and Impacts on Small-Scale Growers in Chile. Bulletin of Latin American Research, 16, 1, pp. 43-56.

ODEPA (2005) “Agricultura Chilena 2014: una perspectiva de mediano plazo". Data available on www.odepa.gob.cl

O'Halleron, M (2007) The big brand that gets it right. Decanter, 33, 1, pp.142-3.

Olavarria, J A, Moreno, Y M, Garcia, M and Monsalvez, C (2008) "Caracterización y Performance Tecnológico en Dos Clusters Vitivinícolas: Valles de Colchagua y Maule". Programa Bicentenario de Ciencia y Tecnología, Santiago. 
Richards, P (2006) The Wines of Chile. London, Mitchell Beazley.

Ross, J (2006) Where Angels Tread: the story of Viña Montes. Santiago: Montes.

Sturgeon, T J (2001) How do we define value chains and production networks? IDS Bulletin, 32, 3, pp.9-18.

Visser, E-J and de Langen, P (2006) The importance and quality of governance in the Chilean wine industry, Geojournal, 65, 177-197

Wines of Chile (2007) Market statistics summary 2003-2007 and press release. Ascot. 